\title{
CORRUPTION AND POST-CONFLICT PEACEBUILDING: SELLING THE PEACE?
}

\section{Cheng, CS and Zaum, D.}

London: Routledge: Taylor and Francis

2013 Reprint Edition,

297 pages

ISBN: 0415721563

Corruption and post-conflict peacebuilding: Selling the peace? is a veritable gold mine. Its organisation is intelligent and coherent, and its range and coverage are appropriately encyclopaedic. This volume deals with the theoretical issues around the concepts of corruption and post-conflict peacebuilding. It analyses the effect of corruption in post-conflict times and peacebuilding on the basis of a particular conceptual framework. Although this conceptual framework serves as the basis of this book, it presents many other theories and empirical evidence to illuminate these complex topics and also draws from every relevant discipline related to the issue of corruption and post-conflict peacebuilding. In this regard, the volume provides numerous examples by citing cases from different countries.

While the focus of this volume is predominantly on political corruption, engaged in by scholars exercising some form of public authority, it cannot be suggested that corruption in the private sector or amongst international actors does not exist, or that it is mostly benign and of little consequence. As reports into corruption amongst contractors and international military personnel in Afghanistan and Iraq have suggested, these forms of corruption have serious implications for international peacebuilding and stabilisation efforts. However, given that successful and sustainable peacebuilding undoubtedly requires local institutions - be they formal or informal - corruption within this context seems an appropriate focus for this inquiry.

The volume is divided into three parts. First, it briefly reports on some of the problems arising from efforts to define corruption and its implications for our analysis, and then examines in greater depth what corruption in a post-conflict

Scientia Militaria, South African Journal of Military Studies, Vol 43, No. 2, 2015, pp. 216-217. doi : $10.5787 / 43-2-1134$ government might look like and what needs to be done by domestic and international leaders to achieve reforms successfully. In addition, it analyses how international aid affects corruption in the domestic context. The second 
part of the volume critically examines and discusses the effect of corruption on peacebuilding practices through a series of case studies by illustrating many of the peacebuilding dynamics identified in the initial part of the book. The book then continues to the cases of countries by highlighting the contested character of corruption, and illustrates how factors such as culture and tradition, historical context and human agency contribute to the relationship between peacebuilding and corruption. The authors take a comparative approach to analyse corruption in Bosnia and Herzegovina, Liberia, Iraq, Afghanistan and Sri Lanka. In the last part of the book, they discuss why anti-corruption measures taken during post-conflict transitions have often not achieved their objectives. The analysis of the volume suggested that the success of these programmes could be ultimately attributed to committed leadership, supportive governance, an enabling environment and optimal timing in implementation.

Corruption is a complex and contested issue. The different definitions of corruption employed by the authors in this volume and their differing assessments of the consequences of corruption for peacebuilding testify to this. These differences reflect divergent views on the role of governance and institutions, different conceptions of peace, and in the case studies, the particular social and political structures of the countries under study. Moreover, these differences merely underline that both context and perspective matter when examining complex social phenomena like corruption, and that care needs to be taken in any effort to apply insights from one case to another.

Corruption and post-conflict peacebuilding: Selling the peace? is definitely worth reading, and at the price, it is a very reasonable investment. This volume should be used in humanitarian and foreign aids programmes and for units of refresher training, be incorporated into academic classes that provide instruction on post-conflict theory, and should be read by anyone interested in the fascinating world of corruption and post-conflict peacebuilding. While corruption and peacebuilding professionals comprise the primary intended audience for this book, anyone with a strong commitment to prevention of corruption in post-war times will find it a unique and worthwhile read. The excellent editing of the volume by Taylor and Francis Press contributes to the interesting and pleasant reading experience.

Seun Bamidele, Ekiti State University, Nigeria 